\title{
C-reactive protein and procalcitonin to discriminate between tuberculosis, Pneumocystis jirovecii pneumonia, and bacterial pneumonia in HIV-infected inpatients meeting WHO criteria for seriously ill: a prospective cohort study
}

Fiona Mendelson ${ }^{1}$, Rulan Griesel ${ }^{2}$, Nicki Tiffin ${ }^{1,3}$, Molebogeng Rangaka ${ }^{4,5}$, Andrew Boulle ${ }^{1,3}$, Marc Mendelson ${ }^{6}$ and Gary Maartens ${ }^{2^{*}}$ (D)

\begin{abstract}
Background: Tuberculosis, bacterial community-acquired pneumonia (CAP), and Pneumocystis jirovecii pneumonia (PJP) are the three commonest causes of hospitalisation in HIV-infected adults. Prompt diagnosis and treatment initiation are important to reduce morbidity and mortality, but are hampered by limited diagnostic resources in resource poor settings. C-reactive protein (CRP) and procalcitonin have shown diagnostic utility for respiratory tract infections, however few studies have focussed on their ability to distinguish between tuberculosis, CAP, and PJP in HIV-infected inpatients.

Methods: We evaluated the diagnostic accuracy of CRP and procalcitonin, compared with composite reference standards, to discriminate between the three target infections in adult HIV-infected inpatients in two district level hospitals in Cape Town, South Africa. Participants were admitted with current cough and danger signs in accordance with the WHO algorithm for tuberculosis in seriously ill HIV-infected patients. Study clinicians were blinded to CRP and procalcitonin results.
\end{abstract}

Results: Two hundred forty-eight participants met study case definitions: 133 with tuberculosis, 61 with CAP, 16 with PJP, and 38 with mixed infection. In the 210 particpants with single infections the differences in median CRP and procalcitonin concentrations between the three infections were statistically significant, but distributions overlapped considerably. CRP and procalcitonin concentrations were highest in the CAP group and lowest in the PJP group. CRP and procalcitonin cut-offs with sensitivities of $\geq 90 \%$ were found for all three target infection pairs, but corresponding specificities were low. Highest receiver operating characteristic areas under the curve for CRP and procalcitonin were for PJP versus tuberculosis and PJP versus CAP (0.68 and 0.71 , and 0.74 and 0.69 respectively).

\footnotetext{
* Correspondence: gary.maartens@uct.ac.za

${ }^{2}$ Division of Clinical Pharmacology, Department of Medicine, University of

Cape Town, Cape Town, South Africa

Full list of author information is available at the end of the article
}

(c) The Author(s). 2018 Open Access This article is distributed under the terms of the Creative Commons Attribution 4.0 International License (http://creativecommons.org/licenses/by/4.0/), which permits unrestricted use, distribution, and reproduction in any medium, provided you give appropriate credit to the original author(s) and the source, provide a link to the Creative Commons license, and indicate if changes were made. The Creative Commons Public Domain Dedication waiver (http://creativecommons.org/publicdomain/zero/1.0/) applies to the data made available in this article, unless otherwise stated. 
(Continued from previous page)

Conclusions: CRP and procalcitonin showed limited value in discriminating between the three target infections due to widely overlapping distributions, but diagnostic accuracy was higher for discriminating PJP from CAP or tuberculosis. Our findings show limitations for CRP and procalcitonin, particularly for discriminiation of tuberculosis form CAP, however they may have greater diagnostic utility as part of a panel of biomarkers or in clinical prediction rules.

Keywords: HIV, Tuberculosis, Bacterial community-acquired pneumonia, Pneumocystis jirovecii pneumonia, C-reactive protein, Procalcitonin, Diagnostic accuracy, WHO algorithm

\section{Background}

Respiratory infections are a major cause for hospital admission in HIV-infected people globally in the antiretroviral era; the commonest being tuberculosis, bacterial community-acquired pneumonia (CAP), and Pneumocystis jirovecii pneumonia (PJP) [1]. Prompt diagnosis and initiation of appropriate treatment is important to reduce mortality in HIV-infected inpatients.

Determining the aetiology of serious infections in inpatients with HIV is challenging, in part due to considerable overlap in the clinical and radiographic presentation of tuberculosis, CAP, and PJP [2]. Atypical presentation and dual infection further compound these diagnostic challenges. Furthermore, there are limitations of current diagnostic methods and limited access to diagnostic tests in resource poor settings [3-5].

WHO's algorithm for the diagnosis of tuberculosis in seriously ill patients [6] recommends broad spectrum antibiotics, that treatment for PJP should be considered (without giving guidance on selection of patients for empiric PJP therapy), using a rapid nucleic acid amplification test (the Xpert MTB/RIF assay) to diagnose tuberculosis, and empiric therapy for tuberculosis if the Xpert MTB/RIF assay is negative or unavailable, and there is no response to antibiotics. Our group recently reported that $91.5 \%$ of patients defined as seriously ill by WHO and who had a current cough were diagnosed with tuberculosis, CAP, and/or PJP [7]. Incorporating simple affordable tests in clinical algorithms to discriminate between these three infections could improve outcomes in seriously ill patients. Two inflammatory biomarkers, C-reactive protein (CRP) and procalcitonin, have shown some diagnostic utility for bacterial respiratory infections $[8,9]$, and CRP has high sensitivity but low specificity for diagnosing HIV-associated tuberculosis [8]. An additional advantage is that both CRP and procalcitonin are available as affordable point-of-care tests $[10,11]$. However, only two studies have examined diagnostic performance of CRP in discriminating between tuberculosis, CAP, and PJP in hospitalised patients with HIV, with conflicting results $[2,13]$. We were unable to find any studies reporting diagnostic accuracy of procalcitonin in discriminating between all three infections.
The purpose of this study was to explore the diagnostic accuracy of CRP and procalcitonin in predicting presence or absence of each of the three major infections in seriously ill, HIV-infected inpatients. Secondary objectives were to describe the extent to which CRP and procalcitonin concentrations differed between the three infections and to determine optimal concentration cut-offs for discriminating those with and without each target infection.

\section{Methods}

\section{Study setting and participants}

We conducted a secondary analysis of a data from a large prospective cohort study [7], which was designed to improve the evidence base for the WHO algorithm for the diagnosis of tuberculosis in seriously ill HIV-infected participants with current cough [3]. Recruitment for the main study took place at two secondary level hospitals in Cape Town, South Africa, serving communities with high HIV and tuberculosis prevalence: G.F. Jooste District Hospital from November 2011 until the hospital's closure in February 2013, and Khayelitsha District Hospital from March 2013 until October 2014.

Inclusion criteria for the main study were: admission into the enrollment facility within the previous $24 \mathrm{~h}, \geq 18$ years of age, known HIV infection, cough of any duration, and at least one WHO-defined danger sign (respiratory rate $>30 / \mathrm{min}$, fever $>39^{\circ} \mathrm{C}$, pulse rate $>120 / \mathrm{min}$, and unable to walk unaided). Exclusion criteria were: anti-tuberculosis treatment that was current, completed in the previous month, or defaulted in the past 6 months (isoniazid preventive therapy was allowed); exacerbation of either congestive cardiac failure or chronic obstructive pulmonary disease; and failure to provide a spontaneous or induced sputum specimen.

For the current study we added the inclusion criterion of a CRP and procalcitonin result, (funding for these two assays only became available after the start of the main study). We also only included participants fulfilling our a priori case definitions for tuberculosis, CAP, and/or PJP. 


\section{Case definitions}

Tuberculosis: positive Mycobacterium tuberculosis culture from any site plus at least one symptom consistent with tuberculosis (cough, fever, night sweats, weight loss). CAP: cough $\leq 14$ days plus one or more additional respiratory symptoms (sputum, breathlessness, chest pain, haemoptysis or fever) plus radiological evidence of pulmonary consolidation (confirmed by a radiologist) [14]. PJP: cough $\leq 3$ months plus radiological evidence of diffuse bilateral interstitial infiltrates (confirmed by a radiologist) plus oxygen saturation $\leq 92 \%$ (adapted from Centers for Disease Control and Prevention case definition) [15].

\section{Investigations}

Three sputum specimens were obtained from each participant. One sample was sent for Gram stain, culture, and sensitivity, and two samples for smear examination with auramine staining for acid-fast bacilli (AFB) and liquid mycobacterial culture (BACTEC ${ }^{\mathrm{TM}}$ MGIT $^{\mathrm{mM}}$ 960; Becton, Dickinson and Company, New Jersey, USA). Mycobaterial blood culture was done on all participants. Mycobacterial culture was done on other specimens when appropriate (e.g. pleural fluid).

CRP (Siemens Advia 1800), procalcitonin (Siemens Advia Centaur XP), and $\beta$-D-glucan assay (Fungitell ${ }^{\mathrm{TM}}$; Associates of Cape Cod, Inc., east Falmouth, MA, USA) were done on stored serum in a batch after the study, therefore these tests had no role in patient management. Laboratory staff were blinded to participant diagnosis and outcome. Assay range for CRP was 4-[304-336] $\mathrm{mg} / \mathrm{L}$, normal range was below $10 \mathrm{mg} / \mathrm{L}$. Assay range for procalcitonin was $<0.02-75 \mu \mathrm{g} / \mathrm{L}$, normal range below $0.02 \mu \mathrm{g} / \mathrm{L}$.

Chest radiographs were performed on admission and retrospectively reviewed by a senior radiologist blinded to diagnoses and results of laboratory investigations.

\section{Statistical analyses}

All analyses were performed using Stata software version 13.0 (StataCorp Inc., College Station, Texas, USA).

Based on our fixed sample size of 210 participants with single respiratory infections, we explored precision to detect $90 \%$ sensitivity for each biomarker for the three target infections, aiming for a maximum $\pm 10 \%$ variation in $95 \%$ confidence intervals (CIs). We estimated a range of CIs of binomial proportions using the Wilson-score interval for smaller sample sizes [16]. Since our data was not normally distributed, a second calculation was made using $85 \%$ of the original sample sizes as suggested by Lehmann et al. [17]. We estimated the 95\% CIs of $90 \%$ sensitivity to be $83-94 \%$ for tuberculosis, $79-96 \%$ for CAP, and 69-99\% for PJP. The small sample size for PJP accounted for wide $95 \%$ confidence intervals. Further details of these sample size calculations are provided in an additional table (see Additional file 1: Table S1).

To detect differences in CRP concentrations between the three target infections, we estimated power for a two-sample means test (assuming unequal variances), based on relevant literature. (Expected means for CRP were approximate due to lack of reported standard deviations for tuberculosis or CAP). Our study had $80 \%$ power and alpha of 0.05 (using $85 \%$ of the original sample size to account for non-normal distribution of CRP and procalcitonin concentrations) to detect a minimum mean concentration difference in CRP between tuberculosis and PJP of $36 \%$, between CAP and PJP of 14\%, and between CAP and tuberculosis of $14 \%$, and a minimum mean concentration difference in procalcitonin of $50 \%$ between tuberculosis and PJP, 62\% between CAP and PJP, and 62\% between CAP and tuberculosis. We were unable to find data on sensitivity estimates for procalcitonin in all three target infections in HIV-infected individuals, therefore calculations were based exclusively on studies reporting CRP measures of diagnostic accuracy. Further details of these sample size calculations are provided in an additional table (see Additional file 1:, Table S2).

Diagnostic accuracy analyses for CRP and procalcitonin were performed for participants fulfilling criteria for one of the three single infection definitions. Participants with mixed infection were analysed separately. In clinical practice, differential diagnostic challenges usually present between two of the target infections and less commonly between all three, hence we calculated diagnostic accuracy measures between infection pairs in addition to each target infection versus the other two.

As distributions of both CRP and procalcitonin were not normally distributed, we used non-parametric statistical tests for continuous variables. Univariate associations between participant baseline characteristics in infection pairs were analysed using the Wilcoxon-Mann-Whitney test for continuous data, and Chi-square test (or Fisher's Exact test if values in a cell were $<5$ ), for categorical data. All probability tests were two-tailed. CRP and procalcitonin values below the detectable limit (BDL) of the assay were substituted with half BDL (in preference to substitution with the assay limit or with zero, both of which have been shown to bias parameter estimates) [18].

Receiver Operating Characteristic (ROC) area under the curve (AUC) analyses were used to explore potential cut-offs for CRP for each target infection using Liu's index [19], which we then used to calculate diagnostic accuracy estimates. Cut-offs were also explored using the WHO 90\% sensitivity recommendation for screening tests for tuberculosis [20]. To mitigate overfitting and improve accuracy of model prediction, we performed cross-validation on all ROC AUC's exceeding 60\% using 
$\mathrm{k}$-fold cross-validation, as the dataset was too small for generation of a training set.

Since there are few studies on the diagnostic accuracy of procalcitonin for infections in HIV-infected patients, we explored cut-offs established for both lower respiratory tract infections (LRTI) and sepsis. Procalcitonin categories for LRTI were: $<0.1 \mu \mathrm{g} / \mathrm{L}$, bacterial infection very unlikely; $0.1-0.25 \mu \mathrm{g} / \mathrm{L}$, localised bacterial infection unlikely; $0.25-0.5 \mu \mathrm{g} / \mathrm{L}$, localised bacterial infection possible; $>0.5 \mu \mathrm{g} / \mathrm{L}$, suggestive of bacterial infection. Procalcitonin categories for systemic bacterial infection / sepsis were: $0.5-2 \mu \mathrm{g} / \mathrm{L}$, systemic infection possible; $2-10 \mu \mathrm{g} / \mathrm{L}$, suggestive of systemic infection; > $10 \mu \mathrm{g} / \mathrm{L}$, severe systemic infection / septic shock [9].

This study conforms to the Standards for Reporting Diagnostic Accuracy Studies (STARD) guidelines [21].

\section{Results}

\section{Participant characteristics}

The participant flow diagram is shown in Fig. 1. Ten participants were excluded due to diagnoses other than the three target infections (meningitis, disseminated Cryptococcus, emmonsia, bronchitis, and post-TB bronchiectasis with a pneumothorax). All participants had received at least one dose of antibiotics as per WHO

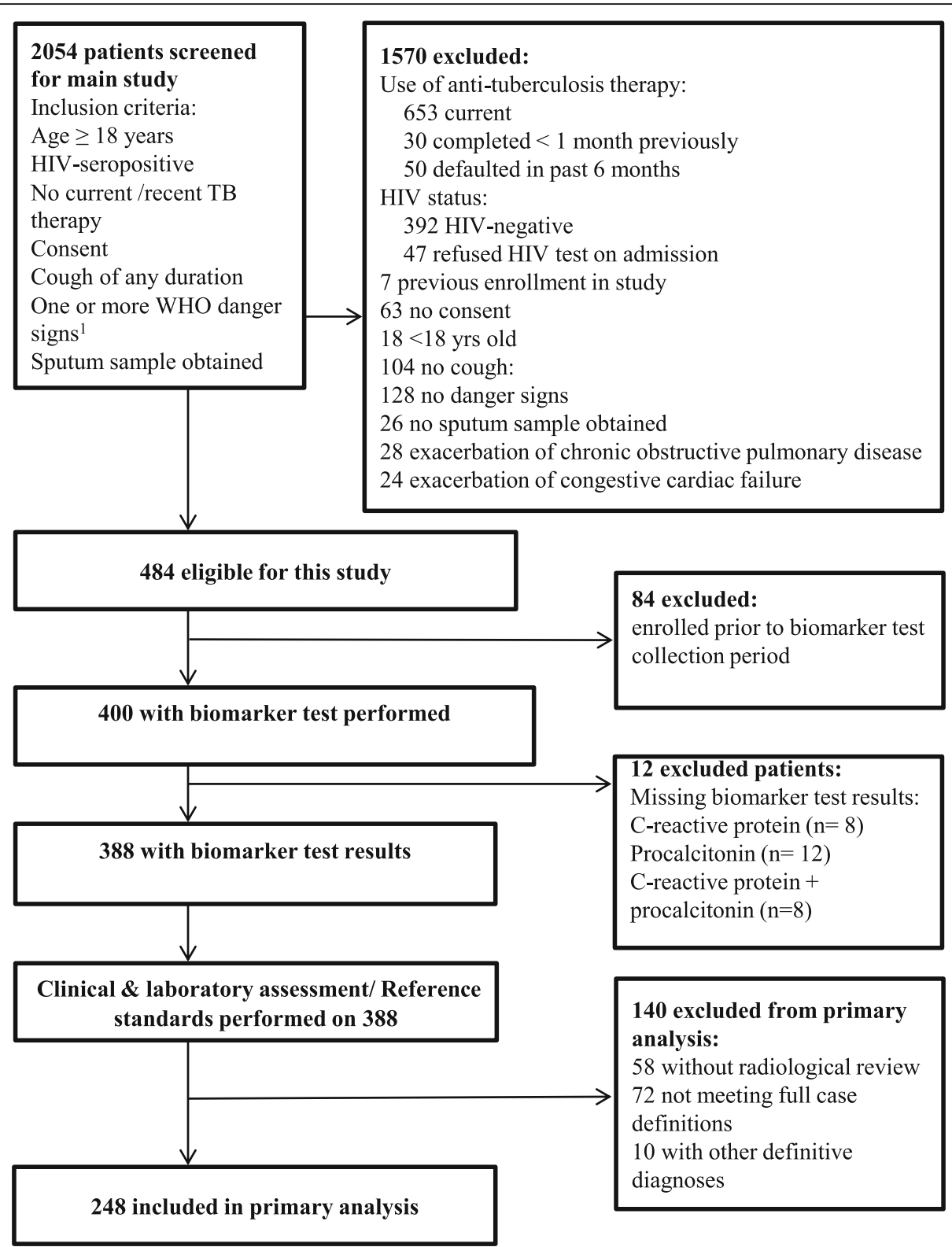

Fig. 1 Consort diagram based on Standards for Reporting Diagnostic Accuracy Studies (STARD) 
guidelines (usually ceftriaxone) prior to obtaining blood samples used for biomarker tests. 73/248 (29\%) reported taking cotrimoxazole prophylaxis prior to admission. Figure 2 summarises the distribution of target infections in all 248 participants.

Baseline characteristics of the 210 paticipants with one of the three single infection diagnoses (i.e. excluding participants with mixed infection) are shown in Table 1 . Tuberculosis was associated with lower haemoglobin concentrations and reported weight loss compared with the other two groups. Inability to walk unaided was more common in those with tuberculosis than in those with CAP. Those with CAP had higher median white cell count and CD4 count than the other two infections. The CAP group was more likely to have been using antiretroviral therapy prior to admission compared with the tuberculosis group. Participants with PJP were much more likely to have $\beta$-D-glucan concentrations exceeding $300 \mathrm{pg} / \mathrm{L}$, had lower CD4 counts, and were more likely to have a respiratory rate above $30 / \mathrm{min}$ than participants in the other two groups.

\section{CRP concentrations and diagnostic utility for each infection}

Distributions of CRP concentrations by single infection category are shown in Fig. 3a. Comparison of CRP concentrations between the three single infections are shown in Table 2. Elevated CRP concentrations (> $10 \mathrm{mg} / \mathrm{L}$ ) were found in 206/210 (98\%) participants: 131/133 (98\%) with tuberculosis, 60/61 (99\%) with CAP, and 15/16 (94\%) with PJP. There were statistically significant differences in median concentrations between

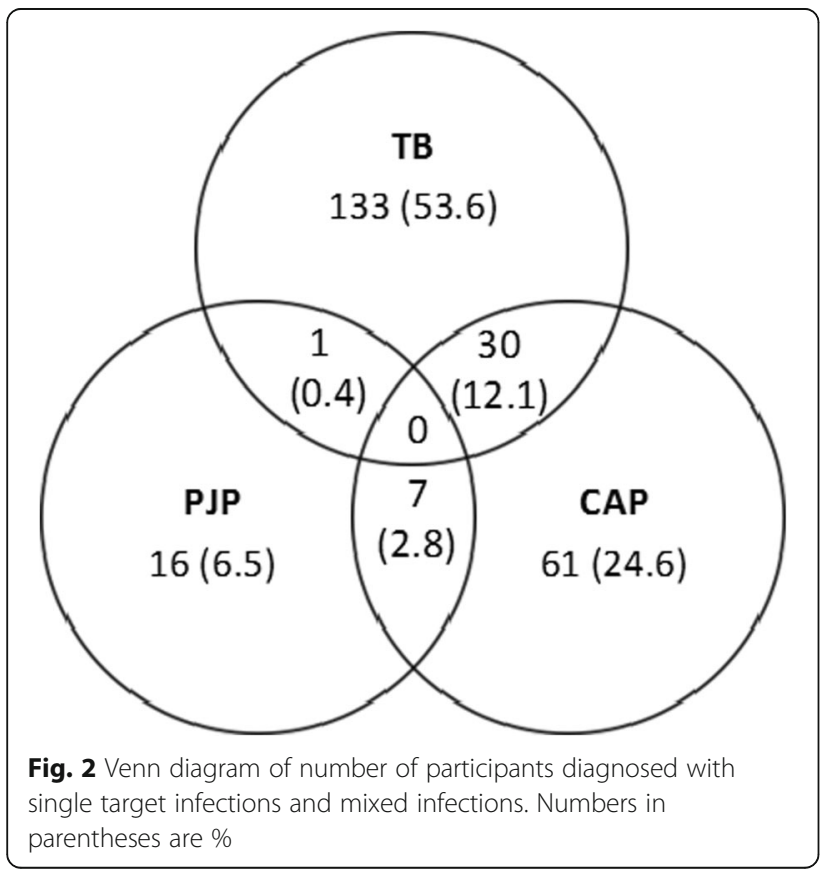

infection pairs, with considerable overlap in distributions. The highest concentrations were in participants with CAP and the lowest concentrations in those with PJP.

ROC AUCs for CRP for each single infection pair are shown in Fig. 4. Cross-validation showed minor reductions of ROC AUCs: from 0.60 to 0.58 (95\% CI: 0.49 0.67 ) in the tuberculosis versus CAP group; from 0.74 to 0.72 (95\% CI: $0.59-0.84$ ) for CAP versus PJP; and from 0.68 to 0.64 (95\% CI: $0.51-0.77)$ for PJP versus tuberculosis. Diagnostic accuracy estimates for two cut-offs for each infection pair and each infection versus the other two infections are presented in Table 3. CRP cut-offs with reasonable diagnostic accuracy were found for PJP versus CAP, PJP versus tuberculosis and PJP versus the other two infections.

\section{Procalcitonin concentrations and diagnostic utility for each infection}

Distributions of procalcitonin category in each of the three target infections are shown in Fig. $3 \mathrm{~b}$ and Table 2. We found highest procalcitonin concentrations in the CAP group and lowest in those with PJP. There were statistically significant differences in median procalcitonin concentrations between the three infection groups, but there was marked overlap in distributions. Diagnostic performance of procalcitonin categories for discriminating between infection pairs is shown in Table 4 . ROC AUCs for procalcitonin for each single infection pair are shown in Fig. 4. Best performance of procalcitonin was in discriminating between CAP and PJP.

\section{Participants with mixed infection}

Analysis of baseline characteristics and biomarker concentrations for those with mixed infection compared with those with single target infections are summarised in an additional table (see Additional file 2). Analysis of both biomarkers showed wide distributions, overlapping with those of the three mono-infections. Elevated CRP was found in all 38 participants with mixed infections. Both CRP and procalcitonin medians were statistically higher in the mixed infection group compared with the PJP group. Three participants had procalcitonin concentrations $<0.1 \mu \mathrm{g} / \mathrm{L}$, all of whom had CAP dual infection (two with tuberculosis and the other with PJP). Procalcitonin $\geq 0.25 \mu \mathrm{g} / \mathrm{L}$ captured 29/37 (78.4) with CAP dual infection, $\geq 0.5 \mu \mathrm{g} / \mathrm{L}$ captured $23 / 37$ (62.2\%), and 14 (37.8\%) exceeded the $\geq 2 \mu \mathrm{g} / \mathrm{L}$ cut-off, 3 of whom had concentrations above $10 \mu \mathrm{g} / \mathrm{L}$.

\section{Discussion}

We evaluated the diagnostic accuracy of CRP and procalcitonin for differentiating between the three major infections affecting HIV-infected adult inpatients. Our study is one of 
Table 1 Baseline characteristics of 210 participants with a single target infection by infection status

\begin{tabular}{|c|c|c|c|c|c|}
\hline Diagnosis n (\%) & $\begin{array}{l}\text { Total } N= \\
210\end{array}$ & $\begin{array}{l}\text { TB } n=133 \\
(63)\end{array}$ & $\begin{array}{l}\text { CAP } n=61 \\
(29)\end{array}$ & $\begin{array}{l}\text { PJP } n=16 \\
\text { (8) }\end{array}$ & $P$-value for pairwise comparison ${ }^{a}$ \\
\hline \multirow{2}{*}{$\begin{array}{l}\text { Median age in yrs. } \\
(\mathrm{IQR})\end{array}$} & \multirow{2}{*}{$\begin{array}{l}34.8 \\
(28.9-40.7)\end{array}$} & \multirow{2}{*}{$\begin{array}{l}34.7 \\
(29.1-40.8)\end{array}$} & \multirow{2}{*}{$\begin{array}{l}35.1 \\
(29.4-40.0)\end{array}$} & \multirow{2}{*}{$\begin{array}{l}36.9 \\
(28.8-41.2)\end{array}$} & TB vs. CAP: 0.96, CAP vs. PJP: 0.84 \\
\hline & & & & & PJP vs. TB: 0.75 \\
\hline \multirow[t]{2}{*}{ Sex: female $n(\%)$} & \multirow[t]{2}{*}{$139(66)$} & \multirow[t]{2}{*}{$84(63)$} & \multirow[t]{2}{*}{$44(72)$} & \multirow[t]{2}{*}{$11(69)$} & TB vs. CAP: 0.22 , CAP vs. PJP: $0.71^{b}$ \\
\hline & & & & & PJP vs. TB: $0.79^{b}$ \\
\hline \multirow{2}{*}{$\begin{array}{l}\text { Cotrimoxazole } \\
\text { prophylaxis }\end{array}$} & \multirow[t]{2}{*}{$60(29)$} & \multirow[t]{2}{*}{$38(29)$} & \multirow[t]{2}{*}{$18(30)$} & \multirow[t]{2}{*}{$4(25)$} & TB vs. CAP: 0.89, CAP vs. PJP: $0.49^{b}$ \\
\hline & & & & & PJP vs. TB: $1.00^{\mathrm{b}}$ \\
\hline \multirow{2}{*}{$\begin{array}{l}\text { Antiretroviral therapy } \\
\text { n (\%) }\end{array}$} & \multirow[t]{2}{*}{$76(36)$} & \multirow[t]{2}{*}{$43(32)$} & \multirow[t]{2}{*}{$29(48)$} & \multirow[t]{2}{*}{$4(25)$} & TB vs. CAP: 0.04, CAP vs. PJP: $0.16^{b}$ \\
\hline & & & & & PJP vs. TB: $0.78^{\mathrm{b}}$ \\
\hline \multirow{2}{*}{ 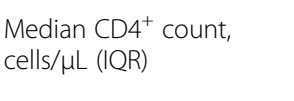 } & \multirow[t]{2}{*}{$97(38-210)$} & \multirow[t]{2}{*}{$77(35-162)$} & \multirow[t]{2}{*}{$200(79-287)$} & \multirow[t]{2}{*}{$35(12-81)$} & TB vs. CAP: 0.0001 \\
\hline & & & & & CAP vs. PJP: 0.0005, PJP vs. TB: 0.03 \\
\hline \multirow{2}{*}{$\begin{array}{l}\text { Median WCC } \times 10^{9} / \mathrm{L} \\
(\mathrm{IQR})\end{array}$} & \multirow{2}{*}{$\begin{array}{l}8.6(5.8- \\
12.9)\end{array}$} & \multirow[t]{2}{*}{$7.3(5.2-10.2)$} & \multirow[t]{2}{*}{$12.3(8.4-20.0)$} & \multirow[t]{2}{*}{$8.2(6.2-10.7)$} & TB vs. CAP: 0.0001, CAP vs. PJP: 0.01 \\
\hline & & & & & PJP vs. TB: 0.5 \\
\hline Median Hb g/dL (IQR) & $9.4(7.7-$ & $8.6(7.4-10.1)$ & $10.4(8.8-12)$ & 11.25 & TB vs. CAP: 0.0001 , CAP vs. PJP: 0.24 \\
\hline & & & & $(9.7-12.2)$ & PJP vs. TB: 0.0001 \\
\hline$\beta$-D-glucan > $300 \mathrm{pg} / \mathrm{mL}$ & $25(12)$ & $11(8)$ & $1(2)$ & $13(80)$ & $\begin{array}{l}\text { TB vs. CAP: } 0.11^{\mathrm{b}} \text {, CAP vs. PJP: }<0.0001^{\mathrm{b}} \text { PJP vs. TB: }< \\
0.0001^{\mathrm{b}}\end{array}$ \\
\hline WHO danger signs ${ }^{c}:$ & & & & & \\
\hline Pulse rate $>$ & $166(79)$ & $106(80)$ & $51(84)$ & $9(56)$ & TB vs. CAP: 0.52, CAP vs. PJP: 0.02 \\
\hline 120 beats/min & & & & & PJP vs. TB: 0.04 \\
\hline Respiratory rate > & $137(65)$ & $83(62)$ & $38(62)$ & $16(100)$ & TB vs. CAP: 0.99, CAP vs. PJP: $0.002^{\mathrm{b}}$ \\
\hline & & & & & PJP vs. TB: $0.001^{\mathrm{b}}$ \\
\hline Fever $>39^{\circ} \mathrm{C}$ & $31(15)$ & $20(15)$ & $10(16)$ & $1(6)$ & TB vs. CAP: 0.81, CAP vs. PJP: $0.44^{b}$ \\
\hline & & & & & PJP vs. TB: $0.47^{b}$ \\
\hline Unable to walk & $119(57)$ & $88(67)$ & $23(38)$ & $8(50)$ & TB vs. CAP: $<0.0001$, CAP vs. PJP: 0.40 \\
\hline & & & & & PJP vs. TB: 0.19 \\
\hline TB symptoms $s^{\mathrm{d}}$ : & & & & & \\
\hline Night sweats & $137(66)$ & $89(67)$ & $38(63)$ & $10(67)$ & TB vs. CAP: 0.58, CAP vs. PJP:1.00 \\
\hline & & & & & PJP vs. TB: $0.78^{\mathrm{b}}$ \\
\hline Weight loss & $196(94)$ & $130(98)$ & $53(88)$ & $13(81)$ & TB vs. CAP: $0.005^{\mathrm{b}}$, CAP vs. PJP: $0.43^{\mathrm{b}}$ \\
\hline & & & & & PJP vs. TB: $0.009^{b}$ \\
\hline Fever & $170(82)$ & $106(80)$ & $52(87)$ & $12(75)$ & TB vs. CAP: 0.29 , CAP vs. PJP: $0.27^{b}$ \\
\hline & & & & & PJP vs. TB: $0.74^{b}$ \\
\hline
\end{tabular}

Abbreviations: TB tuberculosis, CAP bacterial community-acquired pneumonia, PJP Pneumocystis jirovecii pneumonia, $\mathrm{H} b$ haemoglobin, $W C C$ white cell count

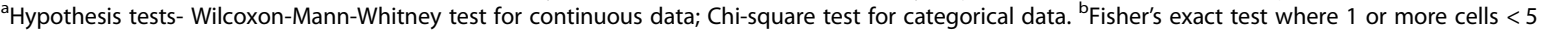

cDanger signs based on WHO algorithm for diagnosis of TB in seriously ill patients; ${ }^{d}$ Cough of any duration was a study inclusion criterion

only a very few to assess the diagnostic accuracy of CRP and procalcitonin for the three commonest infections in HIV-infected inpatients. We found statistically significant differences in median CRP and procalcitonin concentrations between the three infection groups, but there was marked overlap in distributions. Participants with PJP had lower CRP and procalcitonin concentrations. Procalcitonin and CRP had ROC AUCs of around 0.7 for discriminating PJP from CAP and tuberculosis in pairwise comparisons, indicating moderate discrimination, but both biomarkers performed less well in discriminating CAP from tuberculosis. A CRP cut-off of $147 \mathrm{mg} / \mathrm{L}$ had high specificity for discriminating PJP from CAP, and high sensitivity for discriminating PJP from tuberculosis. We found cut-offs with sensitivities of $90 \%$ or more for CRP for all three target infection pairs, and for procalcitonin for two target infection pairs (tuberculosis versus PJP and CAP versus PJP), but specificities were much lower than the $70 \%$ recommended by WHO for tuberculosis screening tests [20]. Our findings suggest that CRP and/or procalcitonin should be explored in the development of clinical prediction 

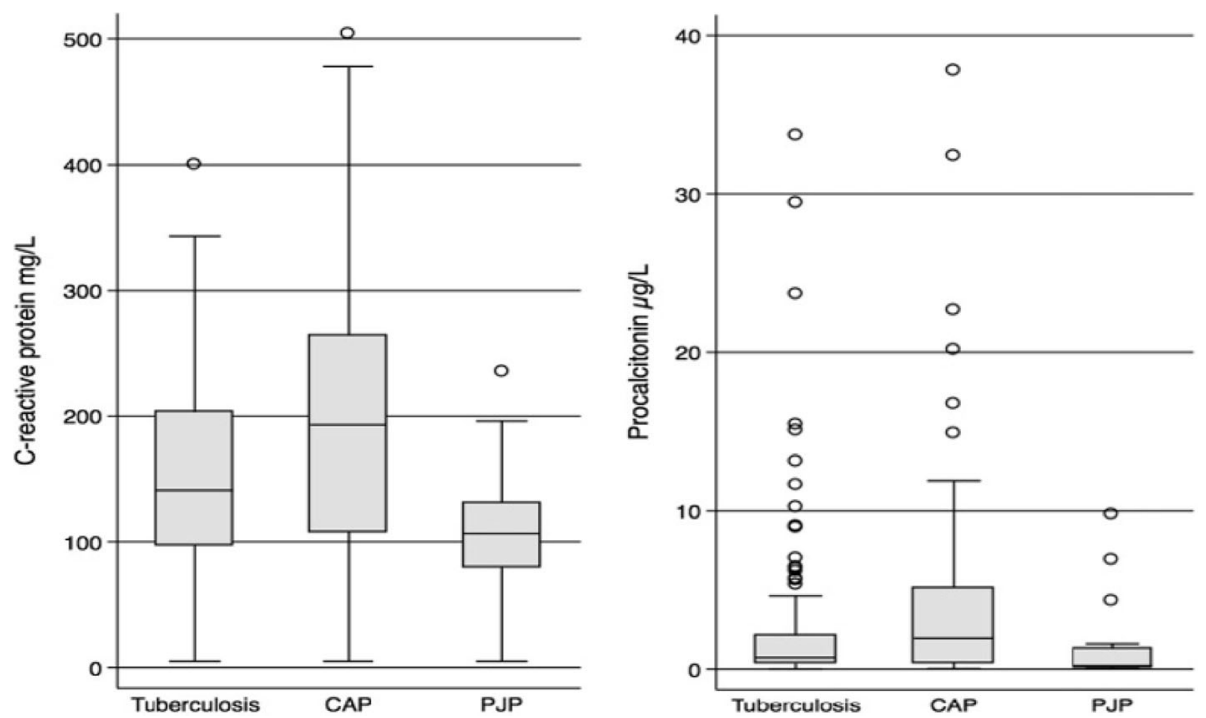

Fig. 3 Distribution of (a) C-reactive protein and (b) procalcitonin in the 210 participants with single infections

rules in seriously ill HIV-infected patients or in a panel of biomarkers rather than be used as stand alone diagnostic tests.

Previous studies have demonstrated the diagnostic value of CRP in active tuberculosis case detection in otherwise healthy HIV-infected persons, however higher false positive rates were found in passive case detection [8]. Elevated CRP is known to occur in all three of our target infections in individuals with HIV, and our finding that
CRP concentrations were highest in CAP, follwed by tuberculosis, and lowest in PJP, is consistent with previous studies $[12,13,22]$. We found that diagnostic performance of CRP in our study population was limited by widely overlapping distributions between the three target infections, resulting in reduced utility for inpatient populations where these are the three commonest competing aetiologies. Similar low specificity for discriminating between all three infections was shown in a British case notes review

Table 2 C-reactive protein and procalcitonin distributions by infection in 210 participants with a single target infection

\begin{tabular}{|c|c|c|c|c|c|}
\hline Biomarker concentration & Total $(N=210)$ & $\mathrm{TB}(n=133)$ & CAP $(n=61)$ & $\operatorname{PJP}(n=16)$ & $P$-value ${ }^{c}$ \\
\hline \multirow[t]{2}{*}{ Median CRP mg/L (IQR) } & $148(96-224)$ & $141(97-203)$ & $193(108-264)$ & $106.5(79.5-131.5)$ & TB vs.CAP: 0.02, CAP vs. PJP: 0.003 \\
\hline & & & & & PJP vs. TB: 0.02 \\
\hline \multirow[t]{2}{*}{ CRP $\geq 10 \mathrm{mg} / \mathrm{L}^{\mathrm{a}} \mathrm{n}(\%)$} & $206(98)$ & $131(98.5)$ & $60(98.4)$ & $15(93.8)$ & TB vs.CAP: $1.00^{d}$, CAP vs. PJP: $0.38^{d}$ \\
\hline & & & & & PJP vs. TB: $0.29^{d}$ \\
\hline \multirow[t]{2}{*}{ Median PCT $\mu \mathrm{g} / \mathrm{L}$ (IQR) } & $0.8(0.3-2.9)$ & $0.7(0.4-2.1)$ & $2.0(0.4-5.2)$ & $0.2(0.1-1.3)$ & TB vs. CAP: 0.05, CAP vs. PJP: 0.01 \\
\hline & & & & & PJP vs. TB: 0.05 \\
\hline$P C T \geq 0.02 \mu \mathrm{g} / \mathrm{L}^{\mathrm{b}}: \mathrm{n}(\%)$ & $209(99.5)$ & $132(99)$ & $61(100)$ & $16(100)$ & - \\
\hline \multirow[t]{2}{*}{$\mathrm{PCT} \geq 0.1 \mu \mathrm{g} / \mathrm{L}: \mathrm{n}(\%)$} & $199(94.8)$ & $128(96.2)$ & $58(95.1)$ & $13(81.3)$ & TB vs. CAP: $0.71^{d}$, CAP vs. PJP: $0.10^{d}$ \\
\hline & & & & & PJP vs. TB: $0.04^{d}$ \\
\hline \multirow[t]{2}{*}{$\mathrm{PCT} \geq 0.25 \mu \mathrm{g} / \mathrm{L}: \mathrm{n}(\%)$} & $170(81)$ & $112(84)$ & $50(82)$ & $8(50)$ & TB vs. CAP: 0.70, CAP vs. PJP: 0.008 \\
\hline & & & & & PJP vs: TB: 0.001 \\
\hline \multirow[t]{2}{*}{ PCT $\geq 0.5 \mu \mathrm{g} / \mathrm{L}: \mathrm{n}(\%)$} & $137(65.2)$ & $87(65.4)$ & $43(70.5)$ & $7(43.8)$ & TB vs. CAP: 0.49, CAP vs. PJP: 0.05 \\
\hline & & & & & PJP vs. TB: 0.11 \\
\hline \multirow[t]{2}{*}{$\mathrm{PCT} \geq 2 \mu \mathrm{g} / \mathrm{L}: \mathrm{n}(\%)$} & $69(32.9)$ & $36(27.1)$ & $30(49.2)$ & $3(18.8)$ & TB vs. CAP: 0.003, CAP vs. PJP: $0.05^{\mathrm{d}}$ \\
\hline & & & & & PJP vs. TB: $0.56^{\mathrm{d}}$ \\
\hline PCT > $10 \mu \mathrm{g} / \mathrm{L}: \mathrm{n}(\%)$ & $16(8)$ & $8(6)$ & $8(13)$ & $0(0)$ & - \\
\hline
\end{tabular}

Abbreviations: CRP C-reactive protein, PCT Procalcitonin, TB tuberculosis, CAP bacterial community-acquired pneumonia, $P J P$ Pneumocystis jirovecii pneumonia ${ }^{a} E$ Elevated concentration. ${ }^{\mathrm{b}}$ Lower detectable limit for procalcitonin assay

'Hypothesis tests- Wilcoxon-Mann_Whitney test for non-normally distributed continuous data and Chi-square test for categorical data

${ }^{\mathrm{d}}$ Fisher's exact test where 1 or more cells $<5$ 

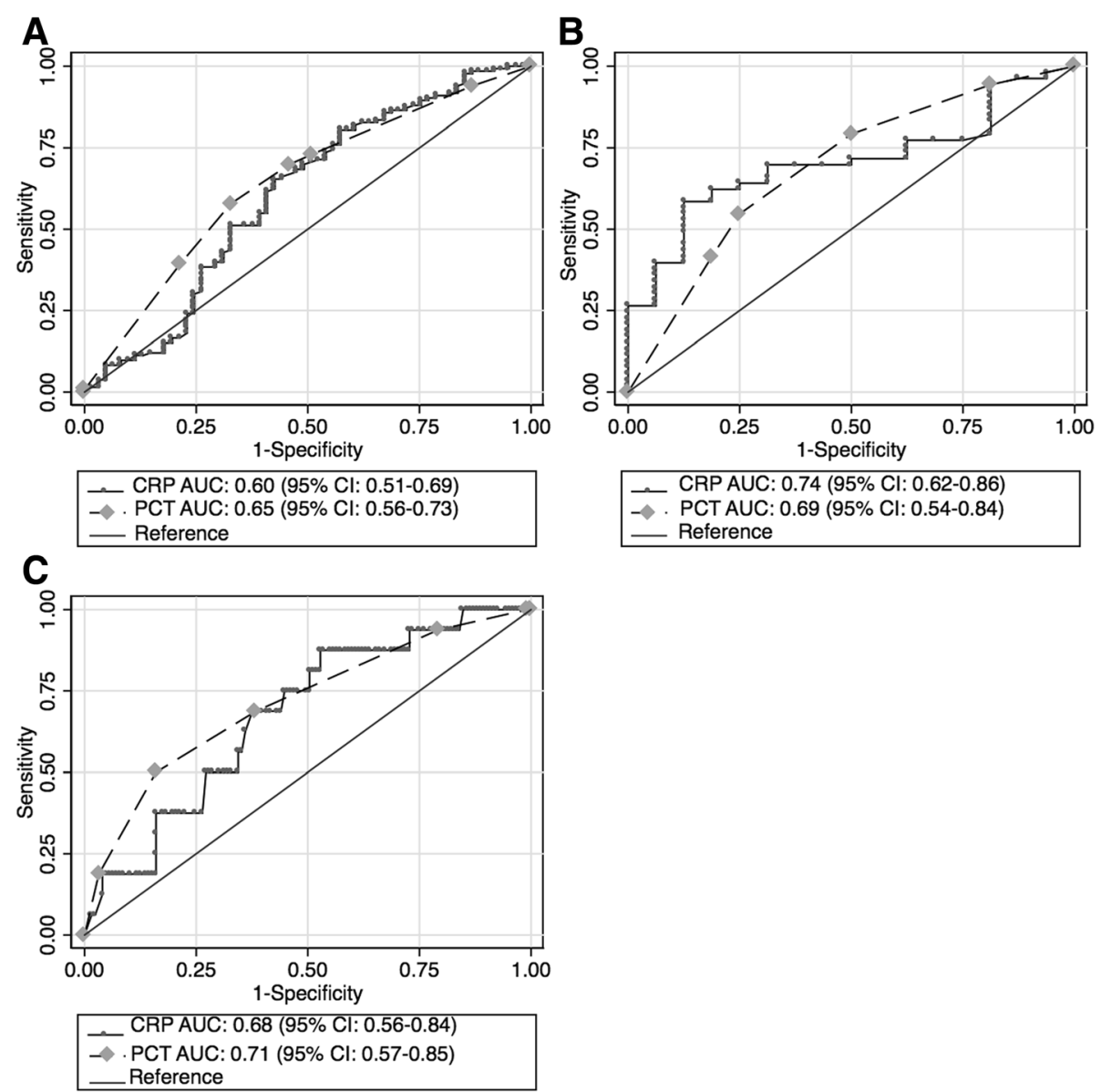

Fig. 4 ROC curves for C-reactive protein and procalcitonin for single infection pairs. a Tuberculosis versus bacterial community-acquired pneumonia, (b) bacterial community-acquired pneumonia versus Pneumocystis jirovecii pneumonia, and (c) Pneumocystis jirovecii pneumonia versus tuberculosis

study of HIV-infected adults admitted with respiratory infections [13]. Conversely, our findings differed from a previous South African study that reported good discrimintaion of CRP (ROC AUC of 0.87) when comparing participants with pneumococcal community-acquired pneumonia and pulmonary tuberculosis [22]. We suspect that the disparity may be attributable to differences in participant selection or to the small sample size in the other South African study. Another study found specificity (83\%) and sensitivity $69 \%$, for combined CRP and IL-8 for discriminating bacerial pneumonia from PJP or mycobateriosis, in a cohort that included hospital-acquired infections and non-tuberculous mycobacterial infections [12].

Guidelines for procalcitonin suggest that bacterial infection is present at a concentration of $\geq 0.25 \mu \mathrm{g} / \mathrm{L}$ [9]. Although this cut-off captured $82 \%$ of participants with CAP in our study, it also identified $84 \%$ of those with tuberculosis and $50 \%$ of those with PJP; therefore had limited value in distinguishing CAP from the other two infections.
Procalcitonin distribution across the three infections in our cohort, with concentrations highest in CAP and lowest in PJP, were comparable to other studies in HIV-infected individuals [22, 23]. However, our findings did not mirror those of two other studies of inpatients with mixed HIV status, both of which found little overlap in procalcitonin concentrations between any of the three target infections [22, 23]. In Schleicher's study, elevated procalcitonin $(>0.1 \mu \mathrm{g} / \mathrm{L})$ was found in all participants with bacterial pneumonia and only $59 \%$ of the tuberculosis group, compared with $95 \%$ and $96 \%$ respectively in our study. Schleicher et al. and Lawn et al. noted a possible link between raised procalcitonin and lower CD4 count $[20,22]$; in our participants with tuberculosis as a single infection we also found a moderate negative association between CD4 count and procalcitonin (Spearman's rho $0.33, p$-value $=0.0001)$. Differing CD4 count medians $(107$ in Schleicher's cohort compared with $77 \times 10^{9}$ cells/L in ours) tuberculosis versus PJP and CAP versus PJP may 
Table 3 Diagnostic accuracy of C-reactive protein by infection pair in 210 participants with single target infections

\begin{tabular}{|c|c|c|c|c|c|c|c|c|}
\hline Infection $^{a}$ & $\begin{array}{l}\text { Cut-off (mg/ } \\
\text { L) }\end{array}$ & $\begin{array}{l}\text { Sensitivity\% (95\% } \\
\text { Cl) }\end{array}$ & $\begin{array}{l}\text { Specificity\% (95\% } \\
\text { Cl) }\end{array}$ & $\begin{array}{l}\text { PPV\% } \\
(95 \% \mathrm{Cl})\end{array}$ & $\begin{array}{l}\text { NPV\% } \\
(95 \% \mathrm{Cl})\end{array}$ & $\begin{array}{l}\mathrm{LR}+(95 \% \\
\mathrm{Cl})\end{array}$ & $\begin{array}{l}\text { LR- }(95 \% \\
\mathrm{CI})\end{array}$ & $\begin{array}{l}\text { Diagnostic odds ratio } \\
(95 \% \mathrm{Cl})\end{array}$ \\
\hline \multirow[t]{2}{*}{ TB vs. CAP } & $C R P \geq 64$ & $90.2(83.9-94.7)$ & $11.5(4.7-22.2)$ & $\begin{array}{l}69.0 \\
(61.5-75.7)\end{array}$ & $\begin{array}{l}35.0 \\
(15.4-59.2)\end{array}$ & $\begin{array}{l}1.02 \\
(0.92-1.13)\end{array}$ & $\begin{array}{l}0.85 \\
(0.36-2.03)\end{array}$ & $1.20(0.45-3.17)$ \\
\hline & $\mathrm{CRP}<175$ & $65.4(56.7-73.4)$ & $57.4(44.1-70.0)$ & $\begin{array}{l}77.0 \\
(68.1-84.4)\end{array}$ & $\begin{array}{l}43.2 \\
(32.2-54.7)\end{array}$ & $\begin{array}{l}1.53 \\
(1.12-2.11)\end{array}$ & $\begin{array}{l}0.60 \\
(0.44-0.83)\end{array}$ & $2.55(1.37-4.72)$ \\
\hline \multirow[t]{2}{*}{ CAP vs. PJP } & $C R P \geq 63$ & $90.2(79.8-96.3)$ & $18.8(4.0-45.6)$ & $\begin{array}{l}80.9 \\
(69.5-89.4)\end{array}$ & $\begin{array}{l}33.3 \\
(7.5-70.1)\end{array}$ & $\begin{array}{l}1.11 \\
(0.86-1.42)\end{array}$ & $\begin{array}{l}0.52 \\
(0.15-1.87)\end{array}$ & $2.12(0.51-8.94)$ \\
\hline & $C R P \geq 147$ & $63.9(50.6-75.8)$ & $87.5(61.7-98.4)$ & $\begin{array}{l}95.1 \\
(83.5-99.4)\end{array}$ & $\begin{array}{l}38.9 \\
(23.1-56.5)\end{array}$ & $\begin{array}{l}5.11 \\
(1.38-18.96)\end{array}$ & $\begin{array}{l}0.41 \\
(0.28-0.60)\end{array}$ & $12.41(2.83-59.7)$ \\
\hline \multirow[t]{2}{*}{ PJP vs. TB } & $C R P \geq 33$ & 93.8 (69.8-99.8) & $2.3(0.5-6.5)$ & $\begin{array}{l}10.3 \\
(5.9-16.5)\end{array}$ & $\begin{array}{l}75.0 \\
(19.4-99.4)\end{array}$ & $\begin{array}{l}0.96 \\
(0.84-1.09)\end{array}$ & $\begin{array}{l}2.77 \\
(0.31-25.08)\end{array}$ & $0.35(0.03-3.54)$ \\
\hline & CRP $<147$ & 87.5 (61.7-98.4) & $48.9(40.1-57.7)$ & $\begin{array}{l}17.1(9.7- \\
27.0)\end{array}$ & $\begin{array}{l}97.0 \\
(89.6-99.6)\end{array}$ & $\begin{array}{l}1.71 \\
(1.33-2.19)\end{array}$ & $\begin{array}{l}0.26 \\
(0.07-0.95)\end{array}$ & $6.69(1.46-30.60)$ \\
\hline \multirow[t]{2}{*}{$\begin{array}{l}\text { TB vs. CAP/ } \\
\text { PJP }\end{array}$} & $\mathrm{CRP} \geq 64$ & $90.2(83.9-94.7)$ & $13.0(6.4-22.6)$ & $\begin{array}{l}64.2 \\
(56.8-71.0)\end{array}$ & $\begin{array}{l}43.5 \\
(23.2-65.5)\end{array}$ & $\begin{array}{l}1.04 \\
(0.94-1.15)\end{array}$ & $\begin{array}{l}0.75 \\
(0.35-1.63)\end{array}$ & $1.38(0.58-3.25)$ \\
\hline & $\mathrm{CRP} \geq 150$ & $48.9(40.1-57.7)$ & $49.4(37.8-61.0)$ & $\begin{array}{l}62.5 \\
(52.5-71.8)\end{array}$ & $\begin{array}{l}35.8 \\
(26.8-45.7)\end{array}$ & $\begin{array}{l}0.96 \\
(0.73-1.28)\end{array}$ & $\begin{array}{l}1.04 \\
(0.78-1.37)\end{array}$ & $0.93(0.53-1.63)$ \\
\hline \multirow[t]{2}{*}{$\begin{array}{l}\text { CAP vs. TB/ } \\
\text { PJP }\end{array}$} & CRP $\geq 63$ & $90.2(79.8-96.3)$ & $10.7(6.3-16.9)$ & $\begin{array}{l}29.3 \\
(22.9-36.3)\end{array}$ & $\begin{array}{l}72.7 \\
(49.8-89.3)\end{array}$ & $\begin{array}{l}1.01 \\
(0.91-1.12)\end{array}$ & $\begin{array}{l}0.92 \\
(0.38-2.23)\end{array}$ & $1.10(0.42-2.87)$ \\
\hline & $\mathrm{CRP} \geq 175$ & $57.4(44.1-70.0)$ & $67.8(59.6-75.2)$ & $\begin{array}{l}42.2 \\
(31.4-53.5)\end{array}$ & $\begin{array}{l}79.5 \\
(71.5-86.2)\end{array}$ & $\begin{array}{l}1.78 \\
(1.30-2.45)\end{array}$ & $\begin{array}{l}0.63 \\
(0.46-0.86)\end{array}$ & $2.83(1.54-5.21)$ \\
\hline \multirow[t]{2}{*}{$\begin{array}{l}\text { PJP vs. TB/ } \\
\text { CAP }\end{array}$} & $C R P \geq 33$ & $93.8(69.8-99.8)$ & $2.6(0.8-5.9)$ & $\begin{array}{l}7.4 \\
(4.2-11.8)\end{array}$ & $\begin{array}{l}83.3 \\
(35.9-99.6)\end{array}$ & $\begin{array}{l}0.96 \\
(0.85-1.09)\end{array}$ & $\begin{array}{l}2.42 \\
(0.30-19.52)\end{array}$ & $0.40(0.04-3.62)$ \\
\hline & $C R P<147$ & 87.5 (61.7-98.4) & $53.6(46.3-60.8)$ & $\begin{array}{l}13.5 \\
(7.6-21.6)\end{array}$ & $\begin{array}{l}98.1 \\
(93.4-99.8)\end{array}$ & $\begin{array}{l}1.89 \\
(1.48-2.40)\end{array}$ & $\begin{array}{l}0.23 \\
(0.06-0.86)\end{array}$ & 8.09 (1.99-36.55) \\
\hline
\end{tabular}

Two cut-offs are listed for each infection pair and one infection versus the other two: the first with minimum $90 \%$ sensitivity and the second selected using the Liu index (see text for details)

Abbreviations: TB tuberculosis, CAP bacterial community-acquired pneumonia, PJP Pneumocystis jirovecii pneumonia, PPV positive predictive value, NPV negative predictive value, LR Likelihood ratio, Cl confidence interval. ${ }^{a}$ Cohort prevalences: TB, $63.3 \%$ (95\%Cl, 56.4-69.9\%); CAP, $29.0 \%$ (95\% Cl, 23.0-35.7\%); PJP, 7.6\% (95\% $\mathrm{Cl}, 4.4-12.1 \%)$

account for higher procalcitonin concentrations in our tuberculosis group.

Mixed infection is a well-recognised limitation in diagnostic accuracy studies. Our study prevalence of $15.3 \%$ mixed infection compared to Nyamande's reported $21 \%$ [23]. In our study, elevated CRP was found in all 38 participants with mixed infection and elevated procalcitonin in 92\%. Our participants with mixed infection had higher median concentrations of both CRP and procalcitonin than the participants with tuberculosis and PJP as single infections, but statistical significance was only found when comparing mixed infection to PJP as a single infection. Due to the difficulty in determining the extent of contribution of each infection to biomarker concentrations, the mixed infection group was excluded from diagnostic accuracy analyses.

Our study has a number of limitations. First, reference standards for CAP and PJP did not include microbiological confirmation. Although blood and sputum cultures were carried out to detect bacterial infections, almost all were negative due to prior antibiotic use. However, even if cultures had been taken prior to antibiotics the sensitivity of sputum and blood cultures for CAP is low, and clinical case definitions of CAP are universally used in clinical research. Bronchoalveolar lavage, which is the optimal specimen for diagnosing PJP, was not available at either of our study hospitals. However, we adapted the CDC case definition for PJP, which has a sensitivity and specificity of 85\% for diagnosis of PJP when compared with bronchoscopy [24]. Furthermore, we found $\beta$-D-glucan exceeding $300 \mathrm{pg} / \mathrm{L}$ in $80 \%$ of our participants fulfilling our PJP case definition, compared with $8 \%$ for tuberculosis and $2 \%$ for CAP. $\beta$-D-glucan had a sensitivity of $92 \%$ and a specificity of $78 \%$ for the diagnosis of PJP in HIV-infected patients in a systematic review [25], and $91 \%$ sensitivity and $92 \%$ specificity for a $\beta$-D-glucan cut-off $>300 \mathrm{pg} / \mathrm{L}$ in one study [26]. Second, our sample size of participants with PJP was small. Third, CRP and procalcitonin concentrations may have been reduced in participants with bacterial infections by antibiotic treatment prior to providing a blood specimen at study enrolment, which would reduce the ability of the biomarkers to discriminate CAP from TB and PJP. However, this is unlikely to have had a major effect as almost all of our participants received antibiotics within $24 \mathrm{~h}$ of study enrolment. Study strengths include the use of a robust culture-based reference standard for tuberculosis and that our study 
Table 4 Diagnostic accuracy of procalcitonin by infection pair in 210 participants with single target infections

\begin{tabular}{|c|c|c|c|c|c|c|c|c|}
\hline Infection pair ${ }^{a}$ & $\begin{array}{l}\text { Cut-off } \\
(\mu \mathrm{g} / \mathrm{L})\end{array}$ & $\begin{array}{l}\text { Sensitivity\% } \\
(95 \% \mathrm{Cl})\end{array}$ & $\begin{array}{l}\text { Specificity\% } \\
(95 \% \text { Cl) }\end{array}$ & $\begin{array}{l}\text { PPV\% } \\
(95 \% \mathrm{Cl})\end{array}$ & $\begin{array}{l}\text { NPV\% } \\
(95 \% \mathrm{Cl})\end{array}$ & LR+ & LR- & $\begin{array}{l}\text { Diagnostic odds ratio } \\
(95 \% \mathrm{Cl})\end{array}$ \\
\hline \multirow[t]{5}{*}{ TB vs. CAP } & PCT $\geq 0.1$ & $\begin{array}{l}96.2 \\
(91.4-98.8)\end{array}$ & $4.9(1.0-13.7)$ & $\begin{array}{l}68.8 \\
(61.6-75.4)\end{array}$ & $37.5(8.5-75.5)$ & $\begin{array}{l}1.01 \\
(0.95-1.08)\end{array}$ & $0.76(0.19-3.10)$ & $1.32(0.34-5.21)$ \\
\hline & $P C T \geq 0.25$ & $\begin{array}{l}84.2 \\
(76.9-90.0)\end{array}$ & $18.0(9.4-30.0)$ & $\begin{array}{l}69.1 \\
(61.4-76.1)\end{array}$ & $\begin{array}{l}34.4 \\
(18.6-53.2)\end{array}$ & $\begin{array}{l}1.03 \\
(0.89-1.18)\end{array}$ & $0.88(0.45-1.70)$ & $1.17(0.53-2.59)$ \\
\hline & $\mathrm{PCT} \geq 0.5$ & $\begin{array}{l}65.4 \\
(56.7-73.4)\end{array}$ & $\begin{array}{l}29.5 \\
(18.5-42.6)\end{array}$ & $\begin{array}{l}66.9 \\
(58.1-74.9)\end{array}$ & $\begin{array}{l}28.1 \\
(17.6-40.8)\end{array}$ & $\begin{array}{l}0.93 \\
(0.76-1.14)\end{array}$ & $1.17(0.75-1.84)$ & $0.79(0.41-1.52)$ \\
\hline & $\mathrm{PCT} \geq 2$ & $\begin{array}{l}27.1 \\
(19.7-35.5)\end{array}$ & $\begin{array}{l}50.8 \\
(37.7-63.9)\end{array}$ & $\begin{array}{l}54.5 \\
(41.8-66.9)\end{array}$ & $\begin{array}{l}24.2 \\
(17.1-32.6)\end{array}$ & $\begin{array}{l}0.55 \\
(0.38-0.80)\end{array}$ & $1.44(1.10-1.88)$ & $0.38(0.20-0.72)$ \\
\hline & $\mathrm{PCT}>10^{\mathrm{b}}$ & $6.0(2.6-11.5)$ & $\begin{array}{l}86.9 \\
(75.8-94.2)\end{array}$ & $\begin{array}{l}50.0 \\
(24.7-5.3)\end{array}$ & $\begin{array}{l}29.8 \\
(23.2-37.1)\end{array}$ & $\begin{array}{l}0.46 \\
(0.18-1.16)\end{array}$ & $1.08(0.97-1.20)$ & $0.42(0.16-1.15)$ \\
\hline \multirow[t]{4}{*}{ CAP vs. PJP } & $P C T \geq 0.1$ & $\begin{array}{l}95.1 \\
(86.3-99.0)\end{array}$ & $18.8(4.0-45.6)$ & $\begin{array}{l}81.7 \\
(70.7-89.9)\end{array}$ & $\begin{array}{l}50.0 \\
(11.8-88.2)\end{array}$ & $\begin{array}{l}1.17 \\
(0.92-1.49)\end{array}$ & $\begin{array}{l}0.26 \\
(0.06-1.180\end{array}$ & $4.46(0.92-21.84)$ \\
\hline & $P C T \geq 0.25$ & $\begin{array}{l}82.0 \\
(70.0-90.6)\end{array}$ & $\begin{array}{l}50.0 \\
(24.7-75.3)\end{array}$ & $\begin{array}{l}86.2 \\
(74.6-93.9)\end{array}$ & $\begin{array}{l}42.1 \\
(20.3-66.5)\end{array}$ & $\begin{array}{l}1.64 \\
(0.99-2.71)\end{array}$ & $\begin{array}{l}0.36 \\
(0.17-0.75)\end{array}$ & $4.55(1.44-14.43)$ \\
\hline & $\mathrm{PCT} \geq 0.5$ & $\begin{array}{l}70.5 \\
(57.4-81.5)\end{array}$ & $\begin{array}{l}56.2 \\
(29.9-80.2)\end{array}$ & $\begin{array}{l}86.0 \\
(73.3-94.2)\end{array}$ & $\begin{array}{l}33.3 \\
(16.5-54.0)\end{array}$ & $\begin{array}{l}1.61 \\
(0.90-2.87)\end{array}$ & $\begin{array}{l}0.52 \\
(0.29-0.94)\end{array}$ & $3.07(1.02-9.26)$ \\
\hline & $\mathrm{PCT} \geq 2$ & $\begin{array}{l}49.2 \\
(36.1-62.3)\end{array}$ & $\begin{array}{l}81.2 \\
(54.4-96.0)\end{array}$ & $\begin{array}{l}90.9 \\
(75.7-98.1)\end{array}$ & $\begin{array}{l}29.5 \\
(16.8-45.2)\end{array}$ & $\begin{array}{l}2.62 \\
(0.92-7.51)\end{array}$ & $\begin{array}{l}0.63 \\
(0.44-0.88)\end{array}$ & $4.19(1.15-15.03)$ \\
\hline \multirow[t]{4}{*}{ PJP vs. TB } & $P C T \geq 0.1$ & $\begin{array}{l}81.2 \\
(54.4-96.0)\end{array}$ & $3.8(1.2-8.6)$ & $9.2(5.0-15.3)$ & $\begin{array}{l}62.5 \\
(24.5-91.5)\end{array}$ & $\begin{array}{l}0.84 \\
(0.67-1.07)\end{array}$ & $\begin{array}{l}4.99 \\
(1.31-18.94)\end{array}$ & $0.17(0.04-0.71)$ \\
\hline & $P C T \geq 0.25$ & $\begin{array}{l}50.0 \\
(24.7-75.3)\end{array}$ & $\begin{array}{l}15.8 \\
(10.0-23.1)\end{array}$ & $6.7(2.9-12.7)$ & $\begin{array}{l}72.4 \\
(52.8-87.3)\end{array}$ & $\begin{array}{l}0.59 \\
(0.36-0.97)\end{array}$ & $\begin{array}{l}3.17 \\
(1.69-5.93)\end{array}$ & $0.19(0.07-0.54)$ \\
\hline & $\mathrm{PCT} \geq 0.5$ & $43.8(19.8-70.1)$ & $34.6(26.6-43.3)$ & $7.4(3.0-14.7)$ & $83.6(71.2-92.2)$ & $0.67(0.38-1.18)$ & $1.63(1.00-2.66)$ & $0.41(0.15-1.14)$ \\
\hline & $\mathrm{PCT} \geq 2$ & $18.8(4.0-45.6)$ & $72.9(64.5-80.3)$ & 7.7 (1.6-20.9) & $88.2(80.6-93.6)$ & $0.69(0.24-1.99)$ & $1.11(0.86-1.44)$ & $0.62(0.18-2.17)$ \\
\hline
\end{tabular}

Selected categories are based on assay guidelines developed for antibiotic use guidance in lower respiratory tract infections and sepsis (see text for details) Abbreviations: TB tuberculosis, CAP bacterial community-acquired pneumonia, PJP Pneumocystis jirovecii pneumonia, PPV positive predictive value, NPV negative predictive value, $L R$ Likelihood ratio, $\mathrm{Cl}$ confidence interval. ${ }^{\mathrm{a}}$ Cohort prevalences: TB, $63,3 \%$ (95\%Cl, 56.4-69.9\%); CAP, $29.0 \%$ (95\% Cl, 23.0-35.7\%); PJP, 7.6\% (95\% Cl, 4.4-12.1\%)

${ }^{\mathrm{b}}$ Analaysis of PCT category of $>10$ was only performed in TB vs. CAP infection pairs as no PJP participants had PCT exceeding $10 \mu \mathrm{g} / \mathrm{L}$

participants were recruited from two urban district hospitals that represent a population typical of high HIV and tuberculosis burden settings.

\section{Conclusions}

CRP and procalcitonin were both found to have limited value in distinguishing between the three common infections due to widely overlapping distributions, particularly between tuberculosis and CAP. Future studies should include a larger sample of participants with PJP definitively diagnosed, as both biomarkers had best diagnostic accuracy for discriminating between PJP and the other two infections in our study. CRP and procalcitonin may have greater diagnostic utility as part of a panel of biomarkers or in clinical prediction rules.

\section{Additional files}

Additional file 1: Power calculations. Table S1. Power calculation for sensitivity estimates for each target infection. Table S2. Power calculation to detect C-reactive protein and procalcitonin concentration differences between target disease pairs (DOCX $19 \mathrm{~kb})$

Additional file 2: Baseline characteristics including participants with mixed infection. (PDF 105 kb)

\section{Abbreviations}

AFB: Acid fast bacilli; AUC: Area under the curve; BDL: Below the detectable limit; CAP: Bacterial community-acquired pneumonia; Cl: Confidence interval; CRP: C-reactive protein; HIV: Human immunodeficiency virus; LRTI: Lower respiratory tract infection; PJP: Pneumocystis jirovecii pneumonia; ROC: Receiver operating characteristic; STARD: Standards for reporting diagnostic accuracy studies; WHO: World Health Organization

\section{Acknowledgements}

The authors would like to acknowledge Dr. Maia Lesosky for her input into the statistical analysis.

\section{Funding}

This work was supported by the National Institutes of Health; grant number R01 Al 96735-01.

Availability of data and materials

The datasets used and/or analysed during the current study are available from the corresponding author on reasonable request.

\section{Authors' contributions}

$M M, M R$, and GM designed the study. FM, MR, AB, and NT analysed and interpreted the data. FM prepared the first draft together with GM. RG made substantial contributions to data acquisition. All authors were involved in drafting the manuscript or revising it critically for important intellectual content, read and approved the final manuscript, and agreed to be accountable for all aspects of the work. 


\section{Ethics approval and consent to participate}

The University of Cape Town's Human Research Ethics Committee approved the study protocol (reference 334/2011). All enrolled participants signed informed consent. Confused participants were enrolled and given the option to continue with participation once they were orientated. If they declined to give consent their data was removed.

\section{Consent for publication}

Not applicable

\section{Competing interests}

MR is a BMC Editorial Borad member. The other authors declare that they have no competing interests.

\section{Publisher's Note}

Springer Nature remains neutral with regard to jurisdictional claims in published maps and institutional affiliations.

\section{Author details}

'School of Public Health and Family Medicine, University of Cape Town, Cape Town, South Africa. ${ }^{2}$ Division of Clinical Pharmacology, Department of Medicine, University of Cape Town, Cape Town, South Africa. ${ }^{3}$ Centre for Infectious Diseases Research Initiative, Institute of Infectious Diseases \& Molecular Medicine, University of Cape Town, Cape Town, South Africa. ${ }^{4}$ Department of Infection \& Population Health, Institute of Global Health, University College London, London, UK. ${ }^{5}$ Department of Medicine, University of Cape Town, Cape Town, South Africa. ${ }^{6}$ Division of Infectious Diseases and HIV Medicine, Department of Medicine, University of Cape Town, Cape Town, South Africa.

Received: 28 March 2018 Accepted: 1 August 2018

Published online: 14 August 2018

\section{References}

1. Ford N, Shubber Z, Meintjes G, Grinsztejn B, Eholie S, Mills EJ, et al. Causes of hospital admission among people living with HIV world-wide: a systematic review and meta-analysis. Lancet HIV. 2015;2(10):e438-44.

2. Feldman C, Brink AJ, Richards GA, Maartens G, Bateman ED. Management of community-acquired pneumonia in adults. Working group of the South African Thoracic Society. SAMJ. 2007;97(12):1296-306.

3. Chegou NN, Hoek KGP, Kriel M, Warren RM, Victor TC, Walzl G. Tuberculosis assays: past, present and future. Expert Rev Anti-Infect Ther. 2011;9(4):457-69.

4. Trebucq A, Enarson DA, Chiang CY, Van Deun A, Harries AD, Boillot F, et al. Xpert ${ }^{\oplus}$ MTB/RIF for national tuberculosis programmes in low-income countries: when, where and how? Int J Tuberc Lung Dis. 2011;15(12):1567-72.

5. Garcia-Vazquez E, Marcos MA, Mensa J, de Roux A, Puig J, Font C, et al. Assessment of the usefulness of sputum culture for diagnosis of community-asquired pneumonia using the PORT predictive scoring system. Arch Intern Med. 2004;164:1807-11.

6. World Health Organization. Consolidated guidelines on the use of antiretroviral drugs for treating and preventing HIV infection. Recommendations for a public health approach. Second edition. http://www.who.int/hiv/pub/arv/arv-2016/en/ Accessed 4 Oct 2017.

7. Griesel R, Stewart A, van der Plas H, Sikhondze W, Rangaka MX, Nicol MP, et al. Optimizing tuberculosis diagnosis in human immunodeficiency virus-infected inpatients meeting the criteria of seriously ill in the World Health Organisation. Clin Infect Dis. 2018;66:1419-26.

8. Yoon C, Chaisson LH, Patel SM, Allen IE, Drain PK, Wilson D, et al. Diagnostic accuracy of C-reactive protein for active pulmonary tuberculosis: a metaanalysis. Int J Tuberc Dis. 2017;21(9):1013-9.

9. Scheutz P, Chiappa V, Briel M, Greenwald L. Procalcitonin algorithms for antibiotic therapy decisions. A systematic review of randomized controlled trials and recommendations for clinical algorithms. Arch Intern Med. 2011; 171(15):1322-31.

10. Yoon C, Simitala FC, Atuhumoza E, Katende J, Mwebe S, Asege L, et al. Point-of-care C-reactive protein-based tuberculosis screening for people living with HIV: a diagnostic accuracy study. The Lancet online 2017. https://doi.org/10.1016/S1473-3099(17)30488-7. Accessed 8 Dec 2017.

11. Corti C, Fally M, Fabricius-Bjerre A, Mortensen K, Jensen BN, Andreassen HF, et al. Point-of-care procalcitonin test to reduce antibiotic exposure in patients hospitalized with acute exacerbation of COPD. Int J Chron Obstruct Pulmon Dis. 2016:11:1381-9.

12. Benito N, Moreno A, Filella X, Miro MJ, Gonzalez J, Pumarola P, et al. Inflammatory responses in blood samples of human immunodeficiency virus-infected patients with pulmonary infections. Clin Diagn Lab Immunol. 2004;11:608-14.

13. Sage EK, Noursadeghi M, Evans HE, Noursadeghi M, Parker SJ, Copas AJ, et al. Prognostic value of $\mathrm{C}$-reactive protein in HIV-infected patients with Pneumocystis jirovecii pneumonia. Int I STD AIDS. 2010;21:288-92.

14. Scott JAG, Hall AJ, Muyodi C, Lowe B, Ross M, Chohan B, et al. Aetiology, outcome, and risk factors for mortality among adults with acute pneumonia in Kenya. Lancet. 2000;355:1225-30.

15. Centers for Disease Control. Revision of the CDC surveillance case definition for Acquired Immunodeficiency Syndrome. Morbidity and mortality weekly report. 1987; 36(suppl no1S): Appendix III p. 13S. https://www.cdc.gov/ mmwr/pdf/other/mmsu3601.pdf Accessed 10 Jan 2017.

16. Agresti A, Coull BA. Approximate is better than "exact" for interval estimation of binomial proportions. Am Stat. 1998;52(2):119-26.

17. Lehmann EL. Nonparametrics: statistical methods based on ranks, revised. Upper Saddle River: Prentice Hall, Inc; 1998. p. 76-81.

18. LaFleur B, Lee W, Merchant N. Statistical methods for assays with limits of detection: serum bile acid as a differentiator between patients with normal colons, adenomas, and colorectal cancer. J Carcinog. 2011;10:12. https://doi. org/10.4103/1477-3163.79681.

19. Liu X. Classification accuracy and cut point selection. Stat Med. 2012;31: 2676-86. https://doi.org/10.1002/sim.4509.

20. World Health Organization. High-priority target product profiles for new tuberculosis diagnostics: report of a concensus meeting. http://www.who. int/tb/publications/tpp_report/en/ Accessed 16 Jun 2017.

21. Bossuyt PM, Reitsma JB, Bruns DE, Gatsonis CA, Glasziou PP, Irwig L, et al. For the STARD Group. STARD 2015: an updated list of essential items for reporting diagnostic accuracy studies. BMJ. 2015;351:h5527.

22. Schleicher GK, Herbert V, Brink A, Martin S, Maraj R, Galpin JS, et al. Procalcitonin and C-reactive protein levels in HIV-positive subjects with tuberculosis and pneumonia. Eur Respir J. 2005;25(4):688-92.

23. Nyamande K, Lalloo UG. Serum procalcitonin distinguishes CAP due to bacteria, Mycobacterium tuberculosis and P.JP. Int J Tuberc Lung Dis. 2006; 10(5):510-5.

24. Miller RF, Millar AB, Weller IVD, Semple SJG. Empirical treatment without bronchoscopy for Pneumocystis carinii pneumonia in the acquired immunodeficiency syndrome. Thorax. 1989;44:559-64.

25. Li WJ, Guo YL, Liu TJ, Wang K, Kong JL. Diagnosis of Pneumocystis pneumonia using serum (1-3)-B-D-glucan: a bivariate meta-analysis and systematic review. J Thorac Dis. 2015;7(12):2214-25.

26. Salerno D, Mushatt D, Myers L, Zhuang Y, de la Rua N, Calderon EJ, et al. Serum and bal beta-D-glucan for the diagnosis of Pneumocystis pneumonia in HIV postive patients. Resp Med. 2014;108:1688-95.

Ready to submit your research? Choose BMC and benefit from

- fast, convenient online submission

- thorough peer review by experienced researchers in your field

- rapid publication on acceptance

- support for research data, including large and complex data types

- gold Open Access which fosters wider collaboration and increased citations

- maximum visibility for your research: over $100 \mathrm{M}$ website views per year

At BMC, research is always in progress.

Learn more biomedcentral.com/submissions 